\title{
Rising maternal circulating GH during murine pregnancy suggests placental regulation
}

\author{
Kathryn L Gatford ${ }^{1,2}$, Beverly S Muhlhausler ${ }^{3}$, Lili Huang ${ }^{4}$, Pamela Su-Lin Sim³, \\ Claire T Roberts ${ }^{1,2}$, Johannes D Velhuis ${ }^{5}$ and Chen Chen ${ }^{4}$
}

${ }^{1}$ Robinson Research Institute, The University of Adelaide, Adelaide, Australia ${ }^{2}$ Adelaide Medical School, The University of Adelaide, Adelaide, Australia

${ }^{3}$ FOOD plus Research Centre, School of Agriculture, Food and Wine, The University of Adelaide, Adelaide, Australia

${ }^{4}$ School of Biomedical Sciences, University of Queensland, St Lucia, Brisbane, Australia

${ }^{5}$ Endocrine Research Unit, Mayo School of Graduate Medical Education, Center for Translational

Science Activities, Mayo Clinic, Rochester, Minnesota, USA

\author{
Correspondence \\ should be addressed \\ to K L Gatford \\ Email \\ kathy.gatford@adelaide.
}

edu.au

\begin{abstract}
Placenta-derived hormones including growth hormone (GH) in humans contribute to maternal adaptation to pregnancy, and intermittent maternal GH administration increases foetal growth in several species. Both patterns and abundance of circulating $\mathrm{GH}$ are important for its activity, but their changes during pregnancy have only been reported in humans and rats. The aim of the present study was to characterise circulating profiles and secretory characteristics of GH in non-pregnant female mice and throughout murine pregnancy. Circulating GH concentrations were measured in whole blood $(2 \mu \mathrm{L})$ collected every $10 \mathrm{~min}$ for $6 \mathrm{~h}$ in non-pregnant diestrus female C57BI/6J mice $(n=9)$, and pregnant females at day 8.5-9.5 (early pregnancy, $n=8$ ), day 12.5-13.5 (mid-pregnancy, $n=7$ ) and day 17.5 after mating (late pregnancy, $n=7$ ). Kinetics and secretory patterns of $\mathrm{GH}$ secretion were determined by deconvolution analysis, while orderliness and regularity of serial GH concentrations were calculated by approximate entropy analysis. Circulating GH was pulsatile in all groups. Mean circulating GH and total and basal GH secretion rates increased markedly from early to mid-pregnancy, and then remained elevated. Pulse frequency and pulsatile GH secretion rate were similar between groups. The irregularity of $\mathrm{GH}$ pulses was higher in all pregnant groups than that in non-pregnant mice. Increased circulating GH in murine pregnancy is consistent with an important role for this hormone in maternal adaptation to pregnancy and placental development. The timing of increased basal secretion from mid-pregnancy, concurrent with the formation of the chorioallantoic placenta and initiation of maternal blood flow through it, suggests regulation of pituitary secretion by placenta-derived factors.
\end{abstract}

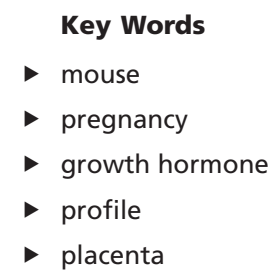

Endocrine Connections (2017) 6, 260-266

\section{Introduction}

Successful pregnancy requires major physiological adaptations in the mother to support pregnancy, and the attachment, implantation, growth and function of the placental interface between mother and foetus (1).
Growth hormone (GH) secretion changes markedly during human pregnancy, as placental synthesis of variant GH in the syncytiotrophoblast increases circulating GH levels and progressively suppresses (c) 2017 The authors
Published by Bioscientifica Ltd

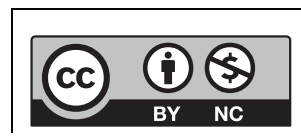

This work is licensed under a Creative Commons Attribution-NonCommercial 4.0 International License. 
pulsatile pituitary secretion from mid-pregnancy $(2,3)$. Placenta-derived hormones including $\mathrm{GH}$ contribute to maternal metabolic adaptations to pregnancy including the progressively increasing insulin resistance, which assists facilitated diffusion of glucose across the placenta to the foetus by elevating maternal glucose concentrations $(4,5,6)$. In contrast to humans, most mammalian species do not produce placental GH (7). Murine placenta expresses placental-specific genes related to prolactin rather than $\mathrm{GH}$, and these act at least in part through the prolactin receptor to contribute to increasing maternal circulating glucose during murine pregnancy (8). These prolactin-related peptides are, however, unlikely to have the same effects as GH, since in mouse prolactin and GH bind poorly to each other's receptors (9). Amongst species lacking placental GH, GH profiles during pregnancy have only been reported in rats (10). In this species, GH remains pulsatile throughout pregnancy, with relatively unchanged pulsatile secretion superimposed on progressively increasing basal secretion (10). In the pregnant mouse, GH measured in single samples increases 30- to 50-fold near term (11), but the patterns of circulating GH during pregnancy have not been reported. Studies in mouse may allow interrogation of regulatory systems through use of knockout and other mutant strains, but first require an understanding of the normal ontogeny of the GH axis during murine pregnancy.

There is good evidence that an increase in maternal GH during pregnancy is likely also important in promoting foetal growth in other mammals. Provided maternal nutrition is adequate, intermittent maternal $\mathrm{GH}$ treatment increases foetal growth in non-human species including rats, pigs and sheep $(12,13,14,15$, $16,17,18)$. Enhanced placental growth and/or function are implicated in these GH-driven increases in foetal growth $(14,15,16,17,18)$. Although daily exogenous $\mathrm{GH}$ administration enhances foetal growth in rats $(16,19,20,16)$, continuous $\mathrm{GH}$ administration does not (21), suggesting that GH pattern as well as dose determine its action, as shown by GH-infusion studies in adult male rats $(22,23)$. Therefore, the aim of this study was to characterise circulating profiles and secretory characteristics of GH in non-pregnant female mice and throughout murine pregnancy.

http://www.endocrineconnections.org DOI: 10.1530/EC-17-0032

\section{Methods}

\section{Animals}

Experimental procedures were approved by the University of Adelaide Animal Ethics Committee (M-2014-167) and carried out in accordance with the Australian code of practice for the care and use of animals for scientific purposes (24). Virgin female and male wildtype C57Bl/6J10-week-old mice were obtained from the Animal Resource Centre, Perth and housed at $23^{\circ} \mathrm{C}$ with 12-h:12-h light:darkness cycle (lights on 06:00 h), with ad libitum access to water and meat-free rat and mouse diet $(14.0 \mathrm{MJ} / \mathrm{kg}, 20 \%$ protein, Speciality Feeds, Glen Forrest, Australia). To minimise stress, all females were handled daily for $\sim 10$ min per mouse for $\geq 14$ day before sampling. Female mice were weighed daily throughout the remainder of the experiment. Estrus stage in females was classified daily by observation of cell types collected by gently flushing the vagina with $10 \mu \mathrm{L}$ of saline each morning (25). To generate timed pregnancies, a male was placed in the females' cage overnight when one or both females were in diestrus-to-proestrus transition or proestrus. Pregnancy was signified by the presence of a vaginal plug (day 0.5), cell types in post-mating estrus smears and/or weight gain and confirmed at post-mortem after sampling.

Blood samples for GH analysis were collected from non-pregnant diestrus females $(n=9)$, and pregnant females at three gestational ages: day 8.5-9.5 (early pregnancy, $n=8$ ), day 12.5-13.5 (mid-pregnancy, $n=7$ ) and day 17.5 after mating (late pregnancy, $n=7$ ). Term in these C57Bl/6J mice is day 19.3 after mating (26). Each animal was sampled on a single day, over a sixhour period to allow patterns of $\mathrm{GH}$ in circulation and of GH secretion to be determined. From 13:00 h, 36 sequential tail-tip blood samples (each $2 \mu \mathrm{L}$ ) were collected at 10-min intervals from each mouse, processed and stored at $-80^{\circ} \mathrm{C}$ for later analysis as previously described (27). Immediately following collection of the final sample, mice were humanely killed by carbon dioxide inhalation, and maternal organ weights (liver, heart, lungs, spleen and kidneys) and gravid uterus were recorded. Numbers of implantations, foetuses and resorption sites were counted and at the two later gestational ages, foetuses were also weighed. Complete suppression of GH secretion was observed in a single mouse in late pregnancy, which had normal litter size

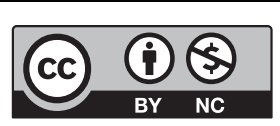

This work is licensed under a Creative Commons Attribution-NonCommercial 4.0 International License. 
and foetal weights at post-mortem. Data for this animal were excluded as a loss of GH secretion occurs acutely in stressed mice (28), and this single animal was therefore not considered to reflect the normal physiology of pregnancy.

\section{Growth hormone analysis}

Analysis for $\mathrm{GH}$ was performed using an in-house mouse GH ELISA as described and validated previously (27). Within- and between-assay coefficients of variation were $2.3 \%$ and $14.7 \%$ ( $n=12$ plates) and all samples from a single mouse (serial samples for analysis of secretion pattern) were analysed on the same ELISA plate. Kinetics and secretory patterns of pulsatile GH secretion were determined by deconvolution analysis following parameters established previously for GH secretion in mouse $(27,28)$. The orderliness and regularity of serial GH serum concentrations were calculated by approximate entropy (ApEn) analysis as described previously; a higher absolute ApEn denotes greater irregularity and indicates a loss in stability of feedback of $\mathrm{GH}$ regulation (29).

\section{Data analysis and statistics}

Effects of gestational age (non-pregnant, early pregnancy, mid-pregnancy and late pregnancy) were analysed by 1-way ANOVA. GH secretion data were natural logtransformed where necessary to achieve equal variances before analysis. Where a gestational age effect was evident, multiple comparisons between pairs of groups were made using Bonferroni post-hoc analysis. Data are presented as mean \pm s.E.M., and $P<0.05$ was considered statistically significant.

\section{Results}

\section{Pregnancy outcomes}

Age at sampling did not differ between groups $(P>0.8$, Table 1). Litter size varied between 5 and 10 foetuses and was similar in all pregnancy groups $(P>0.05$ for each comparison, Table 1). Resorption sites could only be distinguished in mid-pregnancy and late pregnancy, varied between none and two per litter and did not differ between these two gestational ages $(P>0.9$, Table 1$)$. Maternal weight at sampling, weight gain during gestation

Table 1 Maternal and pregnancy characteristics at sampling.

\begin{tabular}{l} 
\\
\hline$n$ animals \\
Gestational age (day) \\
Age (weeks) \\
Maternal weight (g) \\
Maternal weight less gravid uterus (g) \\
Gestational weight gain (g) \\
Litter size \\
Fetuses $(n)$ \\
Resorption sites ( $n$ ) \\
Total $(n)$ \\
Average fetal weight (g) \\
Maternal body composition \\
Liver $(g)$ \\
Liver $(\%)$ \\
Heart $(g)$ \\
Heart $(\%)$ \\
Lungs $(g)$ \\
Lungs $(\%)$ \\
Spleen $(g)$ \\
Spleen $(\%)$ \\
Kidneys $(g)$ \\
Kidneys $(\%)$ \\
Uterus $(g)$ \\
Uterus $(\%)$ \\
\end{tabular}

$\begin{gathered}\text { Non-pregnant } \\ \text { diestrus }\end{gathered}$
9
$0 \pm 0$
$14.4 \pm 0.3$
$22.1 \pm 0.3^{a}$

\begin{tabular}{c}
\hline $\begin{array}{c}\text { Early pregnancy } \\
\text { (day 8.5-9.5) }\end{array}$ \\
\hline 8 \\
$8.88 \pm 0.18$ \\
$13.8 \pm 0.4$ \\
$23.8 \pm 0.4^{\mathrm{b}}$
\end{tabular}

\begin{tabular}{c}
$\begin{array}{c}\text { Mid-pregnancy } \\
\text { (day 12.5-13.5) }\end{array}$ \\
\hline 7 \\
$12.79 \pm 0.18$ \\
$14.2 \pm 0.2$ \\
$28.1 \pm 0.5^{c}$
\end{tabular}

\begin{tabular}{c}
$\begin{array}{c}\text { Late pregnancy } \\
\text { (day 17.5) }\end{array}$ \\
\hline 6 \\
$17.5 \pm 0$ \\
$13.8 \pm 0.2$ \\
$35.4 \pm 0.4^{d}$ \\
\\
$15.9 \pm 0.3^{\mathrm{c}}$ \\
\\
$6.83 \pm 0.31$ \\
$0.33 \pm 0.21$ \\
$7.17 \pm 0.40$ \\
$1.02 \pm 0.03^{\mathrm{b}}$ \\
\\
$1.41 \pm 0.10^{\mathrm{c}}$ \\
$5.51 \pm 0.42^{\mathrm{b}}$ \\
$0.145 \pm 0.011$ \\
$0.56 \pm 0.04$ \\
$0.138 \pm 0.005$ \\
$0.54 \pm 0.01^{\mathrm{b}}$ \\
$0.103 \pm 0.010^{\mathrm{a}, \mathrm{c}}$ \\
$0.40 \pm 0.03^{\mathrm{a}}$ \\
$0.311 \pm 0.013$ \\
$1.21 \pm 0.04$ \\
$9.71 \pm 0.27^{\mathrm{c}}$ \\
$27.4 \pm 0.7^{\mathrm{c}}$ \\
\hline
\end{tabular}

Data are means \pm S.E.M. Within a row, means with a different superscript letter differ $(P<0.05$ after Bonferroni correction). NA $=$ not applicable. Relative maternal organ weights are expressed as a percentage of maternal weight less gravid uterus weight to avoid confounding effects of litter size.

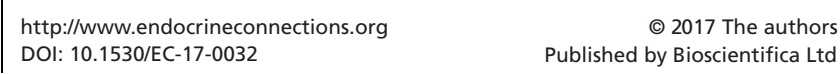

$$
3.2 \pm 0.4^{a}
$$$$
8.13 \pm 0.35
$$$$
\text { NA }
$$$$
8.13 \pm 0.35
$$$$
\text { NA }
$$

$$
\begin{gathered}
1.12 \pm 0.03^{\mathrm{b}} \\
4.83 \pm 0.12^{\mathrm{b}} \\
0.127 \pm 0.006 \\
0.55 \pm 0.03 \\
0.135 \pm 0.004 \\
0.58 \pm 0.02^{\mathrm{a}, \mathrm{b}} \\
0.132 \pm 0.006^{\mathrm{b}, \mathrm{c}} \\
0.57 \pm 0.03^{\mathrm{b}} \\
0.287 \pm 0.016 \\
1.23 \pm 0.07 \\
0.51 \pm 0.09^{\mathrm{a}}
\end{gathered}
$$$$
2.1 \pm 0.3^{a}
$$

$7.57 \pm 0.48$
$0.43 \pm 0.30$
$8.00 \pm 0.22$
$0.15 \pm 0.02^{\mathrm{a}}$

$1.39 \pm 0.06^{\mathrm{c}}$
$5.70 \pm 0.25^{\mathrm{b}}$
$0.132 \pm 0.002$
$0.54 \pm 0.01$
$0.147 \pm 0.006$
$0.60 \pm 0.02^{\mathrm{a}, \mathrm{b}}$
$0.165 \pm 0.017^{\mathrm{b}}$
$0.67 \pm 0.07^{\mathrm{b}}$
$0.304 \pm 0.005$
$1.24 \pm 0.02$
$3.61 \pm 0.35^{\mathrm{b}}$
$12.8 \pm 0.7^{\mathrm{b}}$

$83+0.31$

$.17 \pm 0.40$

$1.41 \pm 0.10^{c}$

$5.51 \pm 0.42^{\mathrm{b}}$

$0.145 \pm 0.011$

$0.138 \pm 0.005$

$0.54 \pm 0.01^{\mathrm{b}}$

$03+0.010^{a}$

$0.311 \pm 0.013$

$.71 \pm 0.27$

$27.4 \pm 0.7$ 


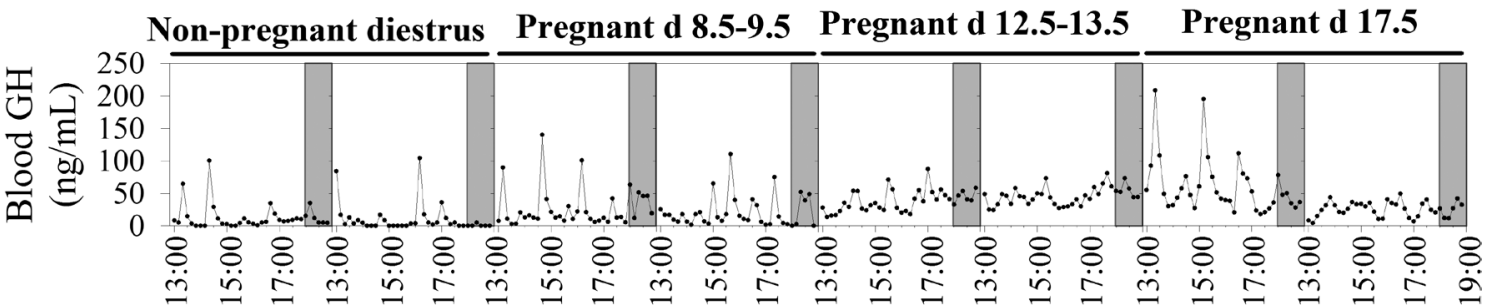

Figure 1

Representative circulating GH profiles in non-pregnant diestrus females and at early, mid- and late pregnancy in the mouse.

and foetal weight each increased with advancing gestation (gestational age effect: $P<0.001$ for each, Table 1 ). Absolute weights of maternal liver and gravid uterus and uterus weight relative to maternal body weight excluding uterus increased with advancing gestation, relative lung weight declined during pregnancy and relative liver weight was greater throughout pregnancy than that in non-pregnant animals (gestational age effect: $P<0.001$ for each, Table 1). Absolute and relative maternal spleen weights were transiently elevated in early and mid-gestation at day 8.5-9.5 and day 12.5-13.5 ( $P<0.01$ compared to nonpregnant or d17.5 of gestation, except for absolute spleen weight at early gestation; Table 1 ).

\section{Maternal GH increases during murine pregnancy}

Circulating $\mathrm{GH}$ was pulsatile in non-pregnant diestrus mice and at all stages of pregnancy studied (Fig. 1). Mean circulating GH and total and basal GH secretion rates were similar in non-pregnant diestrus mice, and in early pregnancy, increased markedly from early- to midpregnancy and then remained elevated in late pregnancy (gestational age effect: $P<0.001$ for each, Table 2). Pulse frequency, mode of secretory bursts and pulsatile $\mathrm{GH}$ secretion rate were similar in non-pregnant diestrus mice and pregnant animals and remained stable throughout pregnancy (gestational age effect: $P>0.1$ for each, Table 2). The irregularity of GH pulses (approximate entropy) was higher at all stages of pregnancy than that in nonpregnant diestrus mice and was greatest at mid-pregnancy (gestational age effect: $P<0.001$, Table 2 ).

\section{Discussion}

In the mouse, as in human and rat $(10,2)$, we observed that circulating GH concentrations increased from midpregnancy. In contrast to humans, but similar to the rat, circulating GH profiles remained pulsatile during pregnancy in mouse $(10,2)$. Also consistent with findings in the rat (10), the increase in average circulating concentrations and total secretion reflected elevation of basal GH secretion, whilst pulsatile GH secretion remained unchanged throughout murine pregnancy. Secretion

Table 2 Circulating growth hormone (GH) and parameters of pulsatile $\mathrm{GH}$ secretion following deconvolution and approximate entropy (ApEn) analysis in C57BI/6J female mice at diestrus and during early, mid- and late pregnancy.

\begin{tabular}{|c|c|c|c|c|}
\hline & $\begin{array}{c}\text { Non-pregnant } \\
\text { diestrus }\end{array}$ & $\begin{array}{c}\text { Early pregnancy } \\
\text { (day 8.5-9.5) }\end{array}$ & $\begin{array}{c}\text { Mid-pregnancy } \\
\text { (day 12.5-13.5) }\end{array}$ & $\begin{array}{c}\text { Late pregnancy } \\
\text { (day 17.5) }\end{array}$ \\
\hline$n$ animals & 9 & 8 & 7 & 6 \\
\hline Mean circulating $\mathrm{GH}$ (ng/mL) & $11.2 \pm 1.9^{a}$ & $18.1 \pm 2.6^{a}$ & $46.6 \pm 7.5^{b}$ & $42.8 \pm 8.6^{b}$ \\
\hline \multicolumn{5}{|l|}{ Deconvolution analysis parameters } \\
\hline Total GH secretion rate (ng/mL $6 \mathrm{~h}$ ) & $505 \pm 84^{a}$ & $779 \pm 130^{a}$ & $2131 \pm 358^{b}$ & $1912 \pm 368^{b}$ \\
\hline Basal GH secretion rate (ng/mL $6 \mathrm{~h}$ ) & $17 \pm 12^{a}$ & $96 \pm 31^{a}$ & $1461 \pm 318^{b}$ & $1085 \pm 273^{b}$ \\
\hline Pulsatile $\mathrm{GH}$ secretion rate (ng/mL $6 \mathrm{~h}$ ) & $489 \pm 77$ & $683 \pm 129$ & $670 \pm 106$ & $827 \pm 186$ \\
\hline Number of $\mathrm{GH}$ pulses/6h & $5.33 \pm 0.37$ & $6.75 \pm 0.62$ & $6.29 \pm 0.42$ & $5.33 \pm 0.56$ \\
\hline Mass of GH secreted/burst (ng/mL) & $94 \pm 13$ & $111 \pm 23$ & $107 \pm 16$ & $180 \pm 55$ \\
\hline Mode of secretory bursts (min) & $11.2 \pm 0.8$ & $9.5 \pm 0.8$ & $10.3 \pm 1.1$ & $11.8 \pm 1.1$ \\
\hline $\operatorname{ApEn}(1,0.35)$ & $0.46 \pm 0.02^{a}$ & $0.70 \pm 0.04^{b}$ & $0.91 \pm 0.04^{c}$ & $0.74 \pm 0.05^{b}$ \\
\hline
\end{tabular}

Data are means \pm S.E.M. Within a row, means with a different superscript letter differ $(P<0.05$ after Bonferroni correction). Data for outcomes indicated by \# were log-transformed prior to statistical analysis to achieve similar variance between groups. The orderliness and regularity of serial GH serum concentrations was calculated by approximate entropy (ApEn) analysis as described previously; a higher absolute ApEn denotes greater irregularity and indicates a loss in stability of feedback of GH regulation (29).

$\begin{array}{lr}\text { http://www.endocrineconnections.org } & \text { ○ } 2017 \text { The authors } \\ \text { DOI: } 10.1530 / \text { EC-17-0032 } & \text { Published by Bioscientifica Ltd }\end{array}$

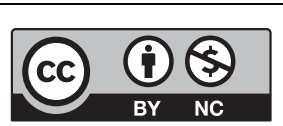

This work is licensed under a Creative Commons Attribution-NonCommercial 4.0 International License. 
of GH during pregnancy also displays high ApEn, or decreased regularity, which indicates a loss in stability of feedback of GH regulation (29). This may reflect either blunting of negative feedback or augmented feed-forward of the system (29); these cannot be differentiated on the basis of circulating profiles alone. Because this increase in circulating GH concentrations and basal GH secretion coincides with the formation of the chorioallantoic placenta and initiation of maternal blood flow through it (30), and the fact that the murine placenta does not express GH (7), we hypothesise that placenta-derived factors regulate changes in GH secretion from the murine pituitary during pregnancy.

Candidate placenta-derived factors that may increase GH secretion during murine and/or rat pregnancy include GH-releasing hormone (GHRH) and ghrelin. Both murine and human placentae express GHRH and ghrelin $(31,32,33)$. Gene and protein expression of ghrelin-O-acyltransferase (MBOAT4), the acetylating enzyme that activates ghrelin, and gene expression of the ghrelin receptor GHRS, have also been reported in human placenta $(33,34,35,36)$. Both of these factors are essential for normal endogenous GH secretion. In contrast to hypothalamic GHRH and somatostatin, which act in conjunction with stomach-derived ghrelin to generate pulsatile GH secretion from the anterior pituitary (37), basal GH secretion increased across pregnancy with little effect on pulsatile secretion, possibly suggesting a stable and increasing placental signal throughout pregnancy. The absence of GHRH induces profound GH deficiency and reduces postnatal growth in mice, leading to a reduction in adult weight of $40-45 \%$ (38). Loss of total or acyl-ghrelin also reduces GH secretion in mice, albeit to a lesser extent $(39,40)$. Intriguingly, litter size is more than halved in homozygous females lacking GHRH, and neonatal mortality is also higher in these pregnancies (38). Litter size is similarly reduced and foetal weight reduced by $\sim 25 \%$ near term in female mice lacking the GH receptor, even when these females are mated to normal males, so that the foetuses and placentae express the $\mathrm{GH}$ receptor (41). This provides further evidence for the importance of maternal GH for pregnancy outcomes in the mouse. The role of endogenous acyl-ghrelin in GH regulation has been studied in mice lacking Mboat4 (membranebound O-acyl transferase 4), the enzyme responsible for octanoylating ghrelin to produce active acyl-ghrelin (35). The recent study of Trivedi and coworkers, in which a single sample of maternal blood was collected from each mouse 18 days after mating, at $0930 \mathrm{~h}, 4 \mathrm{~h}$ after lights on, showed normal increases in maternal circulating GH during pregnancy in the Mboat4-knockout mouse (11), although it is possible that the circulating pattern is perturbed. This contrasts with decreased GH secretion in young male Mboat4-knockout mice (40) and suggests that acyl-ghrelin is not the driver of pregnancy-associated $\mathrm{GH}$ increases in the pregnant mouse. Placenta-derived GHRH may therefore be the more plausible candidate to explain the increasing pituitary GH secretion during murine pregnancy but further studies are required to test this hypothesis, including measures of circulating GHRH.

Increased circulating $\mathrm{GH}$ in murine pregnancy is consistent with changes during human and rat pregnancy and suggests a potentially important role for GH for maternal adaptations to pregnancy and placental development is conserved across multiple species. The timing of increased basal secretion from mid-pregnancy suggests regulation of pituitary secretion by a placentaderived factor. The approach established in the present study will enable us to investigate the mechanisms responsible for the regulation of $\mathrm{GH}$ secretion during pregnancy in the mouse, and its importance for maternal adaptations and placental development and function essential for successful pregnancy.

\section{Declaration of interest}

The authors declare that there is no conflict of interest that could be perceived as prejudicing the impartiality of the research reported.

\section{Funding}

This work did not receive any specific grant from any funding agency in the public, commercial, or not-for-profit sector.

\section{Author contribution Statement}

K L G, B S M, C T R and C C were responsible for the conception and design of the study and drafting the article. $K L G$ and $P$ S-S were responsible for sample generation, $L H$ was responsible for sample analysis, $K L$ G, B S M, C T R, J D V and C C were responsible for data analysis and interpretation, and all authors edited and approved the final version of the manuscript.

\section{Acknowledgements}

Preliminary results from this study were presented at the Endocrine Society of Australia Annual General Meeting in 2016.

\section{References}

1 Roberts CT. IFPA Award in Placentology Lecture: complicated interactions between genes and the environment in placentation, pregnancy outcome and long term health. Placenta 201031 (Supplement) S47-S53. (doi:10.1016/j.placenta.2010.01.001) http://www.endocrineconnections.org DOI: 10.1530/EC-17-0032 (c) 2017 The authors Published by Bioscientifica Ltd
This work is licensed under a Creative Commons Attribution-NonCommercial 4.0 International License. 
2 Eriksson L, Frankenne F, Eden S, Hennen G \& Vonschoultz B. Growth-hormone secretory profiles in pregnancy - lack of pulsatility for the secretion of the placental variant. British Journal of Obstetrics and Gynaecology 198996 949-953. (doi:10.1111/j.1471-0528.1989. tb03352.x)

3 Lacroix MC, Guibourdenche J, Frendo JL, Muller F \& Evain-Brion D. Human placental growth hormone - a review. Placenta 200223 S87-S94. (doi:10.1053/plac.2002.0811)

4 Catalano PM, Tyzbir ED, Roman NM, Amini SB \& Sims EAH. Longitudinal changes in insulin release and insulin resistance in nonobese pregnant women. American Journal of Obstetrics and Gynecology 1991165 1667-1672. (doi:10.1016/0002-9378(91)90012-g)

5 Lager S \& Powell TL. Regulation of nutrient transport across the placenta. Journal of Pregnancy 20122012179827. (doi:10.1155/2012/179827)

6 Newbern D \& Freemark M. Placental hormones and the control of maternal metabolism and fetal growth. Current Opinion in Endocrinology, Diabetes, and Obesity 201118 409-416. (doi:10.1097/ MED.0b013e32834c800d)

7 Papper Z, Jameson NM, Romero R, Weckle AL, Mittal P, Benirschke K, Santolaya-Forgas J, Uddin M, Haig D, Goodman M, et al. Ancient origin of placental expression in the growth hormone genes of anthropoid primates. PNAS 2009106 17083-17088. (doi:10.1073/ pnas.0908377106)

8 Rawn SM, Huang C, Hughes M, Shaykhutdinov R, Vogel HJ \& Cross JC. Pregnancy hyperglycemia in prolactin receptor mutant, but not prolactin mutant, mice and feeding-responsive regulation of placental lactogen genes implies placental control of maternal glucose homeostasis. Biology of Reproduction 201593 75. (doi:10.1095/ biolreprod.115.132431)

9 Bartke A \& Kopchick JJ. The forgotten lactogenic activity of growth hormone: important implications for rodent studies. Endocrinology 2015156 1620-1622. (doi:10.1210/en.2015-1097)

10 El-Kasti MM, Christian HC, Huerta-Ocampo I, Stolbrink M, Gill S, Houston PA, Davies JS, Chilcott J, Hill N, Matthews DR, et al. The pregnancy-induced increase in baseline circulating growth hormone in rats is not induced by ghrelin. Journal of Neuroendocrinology $2008 \mathbf{2 0}$ 309-322. (doi:10.1111/j.1365-2826.2008.01650.x)

11 Trivedi A, Babic S, Heiman M, Gibson WT \& Chanoine JP 2015 Acylated ghrelin is not required for the surge in pituitary growth hormone observed in pregnant mice. Peptides 65 29-33. (doi:10.1016/j.peptides.2015.01.005)

12 de Boo HA, Eremia SC, Bloomfield FH, Oliver MH \& Harding JE. Treatment of intrauterine growth restriction with maternal growth hormone supplementation in sheep. American Journal of Obstetrics and Gynecology 2008199 559.e1-559.e9. (doi:10.1016/j. ajog.2008.04.035)

13 Gatford KL, Boyce JM, Blackmore K, Smits RJ, Campbell RG \& Owens PC. Long-term, but not short-term, treatment with somatotropin during pregnancy in underfed pigs increases the body size of progeny at birth. Journal of Animal Science 2004 82 93-101. (doi:10.2527/2004.82193x)

14 Gatford KL, Owens JA, Campbell RG, Boyce JM, Grant PA, De Blasio MJ \& Owens PC. Treatment of underfed pigs with GH throughout the second quarter of pregnancy increases fetal growth. Journal of Endocrinology 2000166 227-234. (doi:10.1677/joe.0.1660227)

15 Harding JE, Evans PC \& Gluckman PD. Maternal growth hormone treatment increases placental diffusion capacity but not fetal or placental growth in sheep. Endocrinology 1997138 5352-5358. (doi:10.1210/endo.138.12.5584)

16 Spencer GS, Robinson GM, Berry CJ \& Dobbie PM. Alteration of maternal growth hormone levels during pregnancy influences both fetal and postnatal growth in rats. Biology of the Neonate $1994 \mathbf{6 6}$ 112-118. (doi:10.1159/000244098)

17 Sterle JA, Cantley TC, Lamberson WB, Lucy MC, Gerrard DE, Matteri RL \& Day BN. Effects of recombinant porcine growth hormone on placental size, fetal growth, and IGF-I and IGF-II concentrations in pigs. Journal of Animal Science 199573 2980-2985. (doi:10.2527/1995.73102980x)

18 Tung E, Roberts CT, Heinemann GK, De Blasio MJ, Kind KL, van Wettere WHEJ, Owens JA \& Gatford KL. Increased placental nutrient transporter expression at midgestation after maternal growth hormone treatment in pigs: a placental mechanism for increased fetal growth. Biology of Reproduction 201287 121-128. (doi:10.1093/ biolreprod/87.s1.121)

19 Clendinnen BG \& Eayrs JT. The anatomical and physiological effects of prenatally administered somatotrophin on cerebral development in rats. Journal of Endocrinology 196122 183-193. (doi:10.1677/ joe.0.0220183)

20 Jørgensen KD, Svendsen O, Agergaard N \& Skydsgaard K. Effect of human growth hormone on the reproduction of female rats. Pharmacology and Toxicology 199168 14-20. (doi:10.1111/j.1600-0773.1991.tb01201.x)

21 Gargosky SE, Owens JA, Walton PE, Owens PC, Wallace JC \& Ballard FJ. Administration of insulin-like growth factor-I, but not growth hormone, increases maternal weight gain in late pregnancy without affecting fetal or placental growth. Journal of Endocrinology 1991130 395-400. (doi:10.1677/joe.0.1300395)

22 Bick T, Hochberg Z, Amit T, Isaksson OGP \& Jansson J-O. Roles of pulsatility and continuity of growth hormone (GH) administration in the regulation of hepatic GH-receptors, and circulating GH-binding protein and insulin-like growth factor. Endocrinology 1992131 423-429. (doi:10.1210/endo.131.1.1612023)

23 Jansson J-O, Albertsson-Wikland K, Eden S, Thorngren K-G \& Isaksson O. Effect of frequency of growth hormone administration on longitudinal bone growth and body weight in hypophysectomized rats. Acta Physiologica Scandinavica 1982114 261-265. (doi:10.1111/j.1748-1716.1982.tb06980.x)

24 National Health and Medical Research Council of Australia 2013 Australian code of practice for the care and use of animals for scientific purposes, 8th edition. Canberra, Australia: Australian Government Publishing Service.

25 Caligioni CS. Assessing reproductive status/stages in mice. Current Protocols in Neuroscience 2009 Appendix 4I. (doi:10.1002/0471142301. nsa04is48)

26 Murray SA, Morgan JL, Kane C, Sharma Y, Heffner CS, Lake J \& Donahue LR. Mouse gestation length is genetically determined. PLoS ONE 20105 e12418. (doi:10.1371/journal.pone.0012418)

27 Steyn FJ, Huang L, Ngo ST, Leong JW, Tan HY, Xie TY, Parlow AF, Veldhuis JD, Waters MJ \& Chen C. Development of a method for the determination of pulsatile growth hormone secretion in mice. Endocrinology 2011152 3165-3171. (doi:10.1210/en.2011-0253)

28 Steyn FJ, Leong JW, Huang L, Tan HY, Xie TY, Nelson C, Waters MJ, Veldhuis JD, Epelbaum J \& Chen C. GH does not modulate the early fasting-induced release of free fatty acids in mice. Endocrinology 2012 153 273-282. (doi:10.1210/en.2011-1681)

29 Veldhuis JD, Johnson ML, Veldhuis OL, Straume M \& Pincus SM. Impact of pulsatility on the ensemble orderliness (approximate entropy) of neurohormone secretion. American Journal of Physiology: Regulatory, Integrative and Comparative Physiology 2001281 R1975-R1985.

30 Pringle KG \& Roberts CT. New light on early post-implantation pregnancy in the mouse: roles for insulin-like growth factor-II (IGF-II)? Placenta 200728 286-297. (doi:10.1016/j. placenta.2006.04.006)

31 Barnard RJ, Southard N, Edens A \& Talamantes F. Growth hormone receptor and growth hormone-binding protein messages in mouse placenta contain the exon analogous to human exon 3. Endocrinology 1993133 1474-1477. (doi:10.1210/ endo.133.3.8365377)

32 Endo H, Yamaguchi M, Farnsworth R, Thordarson G, Ogren L, Alonso FJ, Sakata M, Hirota K \& Talamantes F. Mouse placental cells

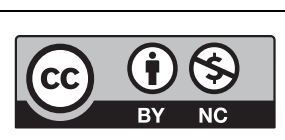

This work is licensed under a Creative Commons Attribution-NonCommercial 4.0 International License. 
secrete immunoreactive growth hormone-releasing factor. Biology of Reproduction 199451 1206-1212. (doi:10.1095/biolreprod51.6.1206)

33 Gualillo O, Caminos JE, Blanco M, Garcia-Cabarello T, Kojima M, Kangawa K, Dieguez C \& Casanueva FF. Ghrelin, a novel placentalderived hormone. Endocrinology 2001142 788-794. (doi:10.1210/ en.142.2.788)

34 Gnanapavan S, Kola B, Bustin SA, Morris DG, McGee P, Fairclough P, Bhattacharya S, Carpenter R, Grossman AB \& Korbonits M. The tissue distribution of the mRNA of ghrelin and subtypes of its receptor, GHS-R, in humans. Journal of Clinical Endocrinology and Metabolism 200287 2988. (doi:10.1210/jc.87.6.2988)

35 Gutierrez JA, Solenberg PJ, Perkins DR, Willency JA, Knierman MD, Jin Z, Witcher DR, Luo S, Onyia JE \& Hale JE. Ghrelin octanoylation mediated by an orphan lipid transferase. PNAS 2008105 6320-6325. (doi:10.1073/pnas.0800708105)

36 Lim CT, Kola B, Grossman A \& Korbonits M. The expression of ghrelin O-acyltransferase (GOAT) in human tissues. Endocrine Journal 201158 707-710. (doi:10.1507/endocri.k11e-117)

37 Veldhuis JD, Anderson SM, Shah N, Bray M, Vick T, Gentili A, Mulligan T, Johnson ML, Weltman A, Evans WS, et al. Neurophysiological regulation and target-tissue impact of the pulsatile mode of growth hormone secretion in the human. Growth Hormone and IGF Research 200111 (Supplement 1) S25-S37. (doi:10.1016/S1096-6374(01)80005-8)

38 Alba M \& Salvatori R. A mouse with targeted ablation of the growth hormone-releasing hormone gene: a new model of isolated growth hormone deficiency. Endocrinology 2004145 4134-4143. (doi:10.1210/en.2004-0119)

39 Hassouna R, Zizzari P, Tomasetto C, Veldhuis JD, Fiquet O, Labarthe A, Cognet J, Steyn F, Chen C, Epelbaum J, et al. An early reduction in GH peak amplitude in preproghrelin-deficient male mice has a minor impact on linear growth. Endocrinology 2014155 3561-3571. (doi:10.1210/en.2014-1126)

40 Xie TY, Ngo ST, Veldhuis JD, Jeffery PL, Chopin LK, Tschop M, Waters MJ, Tolle V, Epelbaum J, Chen C, et al. Effect of deletion of ghrelin-O-acyltransferase on the pulsatile release of growth hormone in mice. Journal of Neuroendocrinology 201527 872-886. (doi:10.1111/ jne.12327)

41 Danilovich N, Wernsing D, Coschigano KT, Kopchick JJ \& Bartke A. Deficits in female reproductive function in GH-R-KO mice; role of IGF-I. Endocrinology 1999140 2637-2640. (doi:10.1210/ en.140.6.2637)

Received in final form 11 April 2017

Accepted 12 April 2017

Accepted Preprint published online 12 April 2017 http://www.endocrineconnections.org DOI: 10.1530/EC-17-0032
(C) 2017 The authors Published by Bioscientifica Ltd

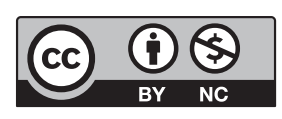

This work is licensed under a Creative Commons Attribution-NonCommercial 4.0 International License. 